\title{
The Significance of Intellectual in Improving the Existence of the Religious Communities Ibn Sina Perspective
}

\author{
Nurul Khair \\ Sekolah Tinggi Filsafat Islam (STFI) Sadra Jakarta \\ Email: Nurulkhair97@gmail.com
}

\begin{abstract}
This paper is a review of Ibn Sina's literature on the significance of reason in increasing religious knowledge. Ibn Sina shared knowledge, hudhuri and husuli. The knowledge of hudhuri is necessary or self-knowledge, so that the truth cannot be doubted. Conversely, knowledge of husuli is non-necessary knowledge which requires argumentation by building prescriptions to justify the information obtained in reality. Ibn Sina studied husuli as a serious discussant in his epistemology study. Perception of the reason is the main basis for justifying information obtained through objects of knowledge, especially religion. Religion contains mystical values that cannot be easily understood through sensory persepsies. Reason is a justification that guides humans to find conclusions that can be objectively justified. However, it is known that the phenomenon of religious communities, especially millennial communities understanding religious values is not based on reason, but rather perceptual power that implies the existence of shahwati and ghodobiyah encouragement, resulting in a radical paradigm in the existence of religious communities. The purpose of this paper is to know the significance of reason for human life and to respond to the fallacy in understanding religious values. The results of this study are knowing the significance of reason in increasing the knowledge and existence of religious communities to understand religious values. The implication is that it forms an anti-radical paradigm and is objective towards religious values.
\end{abstract}

Keywords: Intellect, Radicals, Religion, Significance

\section{INTRODUCTION}

Humans know of two domains of science, namely the internal and external realms. These two domains are media acquiring knowledge. Based on these two domains, humans have different views in understanding the object of knowledge in reality. Some people believe the external domain is the main media in getting knowledge (Robinson, 2003). They argue that internal media - called the concept realm - cannot project science without the existence of external domain reflections - so-called external realms (Bidhendi, 1999). Humans acquire knowledge through perception of material objects. The object of perception is abstracted by intellect, so as to produce a concept or description of matter in the realm of concept. The internal domain does not get a picture without the process of perception in the external realm (Kalin, 2010). Meanwhile, some people think that knowledge can be obtained through the realm of concepts. Concept nature can reveal the nature of reality independently without reflection on external nature (Ziai, 2012).

Differences in views about knowledge are influenced by the foundation of acquiring knowledge. Humans who view the external nature as a medium to gain knowledge are based on their perception power. Perceptual power involves the power of the senses and the experience of human material so that all forms of knowledge are obtained through vision, hearing, feeling, and so on (Kalin, 2010). Knowledge-based on perception will produce a particular, narrow, rigid, and subjective paradigm (Pals, 2012). For example Ahmad saw that the car was red on the Sunan Kalijaga
University yard. Ahmad's knowledge of the car is red (the object of perception) based on his vision. Ahmad will see the red prediction only applies to the car, as well as its vision. Ahmad will have this knowledge, unless he sees a red prediction of another subject in reality. On the other hand Ahmad will refute various knowledge information beyond his powers of vision. As a result, Ahmad's paradigm is closed and skeptical of other objects of reality.

In religious discourse, it is known that human knowledge influences the values of their beliefs. Sigmund Freud in his Totem and Taboo explains that the knowledge of primitive society on the concept of religion is influenced by the power of perception. Humans feel the impermanence of themselves in the external realm, as natural events kill and burden their psychic (Freud, 2015). Based on these feelings, humans feel fear in themselves. Humans create an absolute concept, to overcome this problem. The absolute concept is obtained through the perception of material objects residing in the external realm. Stones, mountains, trees, and statues are seen as locus of absolute soul residing. Then, humans form a tradition and symbolism as a form of respect for material objects (Smith, 2015).

The knowledge of primitive people in discovering the absolute nature has similarities with the understanding of modern society - the $19^{\text {th }}$ to $21^{\text {st }}$ centuries. Modern society understands religious symbols, such as flags, books, mosques, etc. Based on empirical logic (Russell, 2018). Empirical logic places sensory knowledge as the main medium for acquiring knowledge. On the other hand, the senses as a means of 
justification for getting the truth (Kartanegara, 2006). As a result, humans have religious interpretations of religious symbols. Humans will maintain their subjective knowledge by building various arguments based on sensory perception of the object.

These various views, create conflicts in the frame of trust. Humans will drop, fight, and kill each other in order to justify their knowledge (Gimball, 2003). As a result, humans do not maintain a truth but maintain their desire and emotions in themselves. This explanation can be proven through the research of the National Commission on Human Rights (HAM) that there has been an increase in cases of violence and restrictions on religious beliefs for the past three years. In 2014, KOMNAS HAM recorded at least 74 cases of religious violence in all parts of Indonesia. This number increased in 2015, as many as 87 cases. In 2016 experienced an increase of 97 cases (KOMNAS HAM, 2016). The explanation, describes the moral decline of religious communities. Modern religious communities act on the basis of lust and emotion in themselves, so that religious communities act outside themselves (Kant, 1998). As a result, humans lose their existence.

Based on the above problems, a solution is needed as a form of attention to the decline of moral and knowledge of modern religious communities. This paper seeks to examine and analyze the significance of persistent perspectives of Ibn Sina in enhancing the existence of religious communities, both paradigmatic existence and ethical existence through the epistemological approach of peripatetic philosophy. In An-Najah, as some parts have been translated by Shamas Constatine explain the significance of reason analyzing various objects of knowledge in reality (Sina, 1984).

Sense analysis produces universal images or concepts through material objects in the external realm. For example Ain saw that the Sunan Kalijaga UIN building was high. The perception of the Sunan Kalijaga Islamic State Islamic University building was abstracted by reason. Intellect gets two different concepts, namely building concepts and height. Both concepts have different concepts. Because the building concept and height are different. However, the concept produced by reason is universal-particular opponent. High predictions for the UIN Sunan Kalijaga building can be attributed to or addressed to other subjects, such as a tall mosque or a high mountain. Understanding related to mosques and mountains is high known independently by reason without the presence of vision in the external realm - as long as it is seen as logical (Humaidi, 2015).

Universal knowledge will influence the morality of religious communities to open themselves to various differences in their analysis of reason. All arguments that are seen as logical and clear will be accepted by reason inevitably, thus avoiding the free interpretation based on human lust and emotion. Attitudes avoiding free interpretations indicate efforts to obtain objective knowledge. Ibn Sina in his peripatetic philosophy explains that truth is objective, so that every human being can accept it. The implication is that humans can achieve absolute truth in a frame of trust (Yusufian, 2014). Ibn Sina explained that humans are thinking animals. Humans must apply their wits in perceiving religious symbols - material objects - so that they know their core meaning. Knowledge of the core meaning of each religious symbol implies that humans can know the nature of God's truth (Sina, 1998). Thus, universal knowledge through reason analysis affects the morality of religious communities in the external realm, so that humans can improve their existence, as they are without any influence outside themselves (Amini, 1997).

Based on the explanation above, it is known that Ibn Sina's view is a breakthrough to overcome the problems of knowledge and morals of religious communities in the modern era. Every religious community can know the nature of truth in reality through a single view is universal (Bahri, 2011). This view leads humans to self-perfection so that humans can enhance their existence through the analysis of reason on religious symbols in reality (Rahman, 1952). Thus, every religious community can feel the meaning of peace and tranquility in the frame of belief. Based on this explanation, the author studies Ibn Sina's thoughts on the significance of reason in increasing the existence of religious communities through several sub-themes, including the meaning of reason, the influence of science on human morality, reason as the faculty of the highest soul, and reason in Ibn Sina's view.

\section{MATERIALS AND METHODS}

This research is using literature study method. The literature study conducted by the author to search on various written sources, whether in the form of books or documents relevant to the topic of significance of intellect in improving the existence of the religious communities Ibn Sina perspective. Combine collected data, analyze, and make decisions.

\section{RESULTS AND DISCUSSION}

\section{The Meaning of Intellect}

The etymology of the word intellect comes from the Arabic language, namely عقلي means mind, ratio, mental, and reason. The word عقلي is the word absorption from the word meaning to realize, understand, and absorb (Munawwir, 1997). In the epistemological discourse of Islamic philosophy, intellect is the main media to acquire knowledge (Gharawiyan, 2012). According to Muhammad Taqi Mizbah Yazdi intellect is a tool to absorb all knowledge in the external world. Intellect absorbs material entities through perceptual power. Perception power gives the message to the mind to abstract 
material entities. The results of these abstractions produce universal knowledge (Yazdi, 2010). On the other hand, Taqi Mizbah Yazdi explained that reason can work independently without perceptual power. Reason can know various abstract concepts, such as the concept of the soul. Humans can know the soul and argue it through the process of contemplation (Yazdi, 2010).

Taqi Mizbah Yazdi's explanation in understanding the concept of reason is influenced by the views of previous philosophers, such as Ibn Rusdy and Mulla Sadra. Ibn Rusdy explains that intellect is the source of human knowledge to get a conceptual picture of everything in reality. The conceptual picture is something fixed and not lost in the human mind (Wahid, 2014). Human knowledge of material objects is eternal in the concept realm, whereas material objects are limited and destroyed in the external realm. Based on this explanation, Ibn Rusdy realized that reason is a source of knowledge for human life.

Ibn Rusdy's explanation regarding the meaning of reason has harmony with Mulla Sadra's view. Mulla Sadra in Hikmah Muta'aliyah explains intellect is an intermediary of human knowledge to realize and understand the nature of truth on the external (Nasr, 2017). Intellect always analyzes various material objects in reality. The process of reason analysis is an attempt to produce universal knowledge in humans (Mutahahhari, 2002). The product of universal knowledge requires objective understanding. Mulla Sadra's view was emphasized by Thabathabai in his Bidayatul Hikmah that intellect is a medium of abstraction to obtain an objective knowledge. The abstraction media will work after obtaining a reflection of the material object in the external realm (Thabathabai, 1997). Humans get two knowledge through reflection, is the nature of the material object the form - and the quality attached to the material object-mahiyah- (Thabathabai, 1997). Humans will realize that existence is fundamental to the quality of material objects, because the quality of material cannot be present or known without the form of material objects (Mutahahhari, 2014). Based on reason analysis, humans can know the nature of material objects.

From the various explanations above, it can be concluded that reason is the source, the media, and the means to produce a mind, mental, and intellectual are universal. The mind, mental, and universal intellect guide humans to know the nature of the material object in the external realm. Ibn Sina in peripatetic philosophy explains that human knowledge or ideas for everything is based on the power of reason (Sina, 1998). Intellect absorbs material objects necessarily, then forms various images or concepts in the mental realm (Nasr, 2003). The description and concept are analyzed by reason, so that humans know a variety of knowledge. This variety of knowledge constructs an understanding related to the nature of matter, so that humans are aware of the unity of the material object (Yazdi, 2010). Understanding the unity of the material object implies an understanding of the absolute form that creates and gives quality to the material object (Yazdi, 2010).

From the various explanations above, it can be known that Muslim philosophers, such as Taqi Mizbah Yazdi, Ibn Rusdy, Thabathabai, and Mulla Sadra view reason as a media epistemology of knowledge - to study and prove ontological-divine values - so that every human being can know and realize the nature of ontological values. However, it should be noted that the views of Muslim philosophers were influenced by Ibn Sina. Ibn Sina was the first Muslim philosopher to examine the significance of reason in the epistemological field towards ontological values (Amini, 2009).

\section{Effect of Science on Human Morals}

The previous discussion has explained the meaning and function of reason in acquiring knowledge. Science gives influence to human morals in the external world. Humans act on the basis of their knowledge, so it is important to know that the source of knowledge is fundamental to human action. In acquiring human knowledge has two media, namely perception and reason (Mashkoor, 2011).

Perceptual power involves emotional strength and desire. Emotional strength will encourage people to act quickly without a long thought process. Humans act to fulfill their desire (Kung, 2017). Humans discuss the problem of honesty, justice, and hard work by compiling various rules and doctrines. Doctrines and rules are made to rectify all its objectives, so honesty, justice and hard work are not understood properly (Piliang, 2011). As a result, human action does not describe itself as a human being but as an animal influenced by its lust and emotional instincts (Mutahahhari, 2011). The implication is that humans do not have awareness in acting. Everything is viewed subjectively and particularly, just as perception obtains images and concepts of matter in reality (Roibin, 2010). The lack of awareness describes the limitations of human existence to their morals and knowledge. Humans desire based on doctrine and rules so that humans lose their human values (Wibowo, 2011). Human existence is not measured based on its existence but is measured through the doctrine and the rules.

Muslim philosophers and western psychiatrists conduct in-depth studies to overcome these problems. Carl Gustav Jung views the product of perception as having produced imaginative knowledge and influencing the community paradigm, especially religious communities (Jung, 2003). Religious communities view all their actions and actions as producing a value. These values will help him on the final day (Pals, 2002). Muslim philosophers, such as Mohsen Gharawiyan, view the phenomenon as based on a lack of reason. According to him, the main role of reason is to sensitize humans to know and understand the meaning of material objectively (Gharawiyan, 2012). 
After knowing and understanding the meaning of material objects, reason will construct propositions through a system of prediction (haml). Predication systems and propositions are reflected by misdaq (objects) in the external realm (Thabathabai, 1997). Examples of constructing propositions through a proposition system:

P1: Every human being thinks.

P2: Ain is a human.

$\mathrm{K}$ : Ain is thinking.

The above propositions obtained through the actions of Ain are thinking in the external realm. The conclusions of the above propositions are obtained through prediction systems, namely Ain (subject) and thinking (predicate). The attitude of Ain thought to describe the nature of himself, both in the realm of external and in the realm of concept realm (Thabathabai, 1997). Every human believes - both conceptually and misdaq- that Ain is a human, because of human Ain, he thinks. Intellect analyzes every action, both deeds and human paradigms realm (Thabathabai, 1997). Reason analysis of human actions will influence his attitude in reality. Humans will act logically following the power of reason analysis and reject all information that is considered a fallacy (not following a reason analysis system) (Nasr, 2017). Based on this explanation, it can be known that humans can improve the existence, both paradigm and action. Humans can act and paradigmatically tolerate, according to the way the mind works that accepts all logical information in reality.

\section{Intellect as Soul Faculty}

Ibn Sina classifies the faculties of the human soul in three parts, namely the faculty of plants, the faculty of animals, and the faculty of intellect. Division of faculties based on human will obtains knowledge in reality (Najati, 2002). Ibn Sina realized that human knowledge influences the existence of him. Ibn Sina's statement is influenced by the morality of mankind in reality. Ibn Sina ignored two early faculties, namely plants and animals. According to him, the faculty of plants and animals do not describe human existence. On the other hand, these two faculties do not lead humans to perfection and happiness (Mansulrudin, 2017). Ibn Sina in his work al-Mabdā wa al-ma'ād explained the perfection of human existence lies in the faculty's practical activities. The faculty of intellect has a relationship with the soul. The relationship of soul and knowledge lies in consciousness. Humans can know their existence through knowledge. The knowledge of delivering the human soul to the point of its activity is to realize the existence of all entities. Based on this explanation, Ibn Sina mentions human perfection influenced by reason.

Ibn Sina divides the faculty of reason in two parts, namely theoretical intellect and practical intellect. Division of faculty of reason is based on the study locus and its application in reality (Sina, 1998). Theoretical intellect examines and examines material objects to obtain ma'rifat al-haq. Ma'rifat al-haq leads humans to the perfection of the human soul. Humans study and study all knowledge, such as religion on the basis of truth by avoiding mastery and satisfaction these two attitudes describe the animal soul for humans (Mutahahhari, 2011). Humans who follow ma'rifat al$h a q$ will feel happiness and peace in the frame of their beliefs.

Perfection and the activity of ma'rifat al-haq will create practical sense. In human perfection, practical reason will guide humans to reach ma'rifat khair. Ma'rifat khair forms the human personality and its surroundings, such as akhlaq (individuals), tadbir manzil (family), and tadbir manazil (community) (Sina, 1998). The more acute the ma'rifat khair, the stronger the human personality and surroundings. Ma'rifat Khair tries to shape attitudes, both paradigm and morality, to be qualified (Sina, 1998). Humans can act and act based on truth, so that emotional problems and lust do not apply to the activities of ma'rifat khair. Thus, theoretical and practical intellect greatly affect human knowledge and morals in the realm of existence. Perfection will both lead humans to soul happiness (Walid, 2012). In nature, humans want happiness to be eternal - soul happiness - in their lives.

\section{Intellect in Ibn Sina Perspective}

Intellect is one of the important discourses in Ibn Sina's peripatetic philosophy. In his work entitled al-Mabdā wa al-ma'ād, Ibn Sina places the discussion of intellect as an epistemological system in peripatetic philosophy (Sina, 1998). Placement of intellect in the epistemology discourse aims to improve human existence through science. According to Ibn Sina, intellect is a source of knowledge. Reason can produce universal knowledge through the power of analysis-based on this explanation, Ibn Sina influenced many philosophers afterward in the epistemological discourse (Nasr, 2003).

Ibn Sina said that the power of intellect analysis affects human perfection in addressing various views outside himself (Rakhmat, 2014). Intellect encourages humans to accept various data-material objects-in reality. The process of receiving data universally describes the attitude of openness and intellect tolerance of everything other than himself. Various data obtained by humans are analyzed radically-profoundly. The main purpose of reason analysis is to get truth values through data in the external realm. Ibn Sina said the perfection of human intellect lies in its attainment of attaining the values of truth (Sina, 1998). Achievement of truth values can be described through ma'rifat haq. Ma'rifat only influences the human paradigm to study and examine material objects through the perspective of truth, so ma'rifat only ignores the aspects of desire and emotional in acquiring knowledge (Walid, 2012).

Ibn Sina in his work al-Mabdā wa al-ma'ād explained the perfection of ma'rifat haq can be known through the realization of ma'rifat khair in reality (Sina, 
1998). Ma'rifat khair influences human morality in reality. The main influence of ma'rifat khair is directing people to move and think based on truth (Sina, 1998). Humans will avoid various actions and thoughts based on delicacy and power. This attitude will build a strong character for human beings, so that humans can achieve happiness. Happiness achieved by humans will affect the surroundings, such as family (tadbir manzil) and society (tadbir manazil) - a form of perfection of ma'rifat khair (Sina, 1998). The implication is that every human being can achieve happiness and awareness in his existence.

Based on the explanation above, it is known that the basis of human existence is achieved through science. Science is useful in intellect analysis. Man who puts reason as a source of knowledge will reach a truth in its existence. Truth in its existence will influence its perspective in viewing and acting-analyzing. The attitude of looking at and acting on truth implies the high existence of the human soul (Najati, 2002). The higher the human mind, the stronger the soul. Thus, every human being can increase his existence through the significance of reason in seeing and acting on everything.

\section{Analysis}

Modern religious communities use perceptions as a source of knowledge to understand religious symbols. Based on this knowledge, religious communities interpret to get the meaning of these symbols. The results of these interpretations are particular, so that their meaning is particular (Gharawiyan, 2012). The particular meaning indicates a difference in the perspective of religious communities. Religious communities have different interpretations to understand a religious symbol. This attitude causes disputes within the paradigm of religious communities (Suryabarta, 2011). Religious communities compile various arguments to adjust their meaning to the scriptures. Every religious community believes its meaning is in line with the scriptures, as well as the suitability

Religious communities will drop in order to protect their understanding, so that every meaning does not describe the truth but fulfills his desire and emotionality (Sartre, 2015). Humans will do everything they can to fulfill their enjoyment and power to justify their understanding. The paradigm requires violence and discrimination in the frame of trust (Freud, 2002). Strong groups can bring down weak groups. As a result, humans do not reach a truth but fulfill their material expectations and goals (Foucault, 2017). The implication is that religious communities experience a moral and paradigm crisis, so as not to overthrow their existence.

Some atheists, such as Ludwig Fueurbach, Sigmund Freud, and Fredrick Nietzsche would argue that religious symbols believed to lead humans to perfection and truth, precisely leading to human destruction and suffering (Pals, 2012). The statement of atheists cannot be justified, because humans understand the symbol of religion based on their perceptual power so that they do not produce the meaning of the symbol. Ibn Sina has realized that the basis of human existence lies in his knowledge (Sina, 1998). Religious communities must change their knowledge base. Intellect is a human substance, so it distinguishes humans from other living things. Ibn Sina explained that human perfection is the actuality of intellect to recognize the nature of truth (Sina, 1998).

Ibn Sina in his work al-Mabdā wa al-ma'ād explains the significance of intellect in improving human existence. Humans can understand the meaning of religious symbols through reason analysis. Intellect analyzes universal religious symbols, so as to produce objective knowledge (Sina, 1998). Intellect builds various basic propositions, with the aim of avoiding subjective interpretations. Every human will accept that basic proposition (Sina, 1998). Basic propositions constructed by reason will produce knowledge that can be accepted by all views.

Intellectual objectivity will influence the paradigm and morals of religious communities to understand meaning of religious symbols. Religious communities will open up and be tolerant of views outside themselves, with the aim of obtaining data and finding the meaning of religious symbols. Open and tolerant attitudes in paradigm and acting describe the existence of the human soul. Ibn Sina explained that reason affects the human soul (Sina, 1998). Humans can perfect their souls through reasoning in the external realm. Intellect influences practical theoretical and human-moral paradigms, so that every human reaches the truth (Sina, 1998). The attainment of truth describes the perfection of human reason.

The perfection of human reason creates ma'rifat $h a q$, so that every human being will perceive his outer understanding as a truth through the perspective of truth (Sina, 1998). In addition to creating ma'rifat haq, intellect creates ma'rifat khair. Ma'rifat khair can be known through the morality of religious communities based on truth. Humans act and act on the basis of truth (Sina, 1998). Humans will avoid various attitudes in interpreting religious symbols based on delicacy, enjoyment, and power. Thus, reason provides significance for the existence of religious communities to know, understand, and realize the meaning of religious symbols. So that every religious community can understand happiness and perfection of its existence in a frame of trust.

\section{CONCLUSIONS}

The results of this study are knowing the significance of reason in increasing the knowledge and existence of religious communities to understand religious values. The implication is that it forms an anti-radical paradigm and is objective towards religious values. 


\section{REFERENCES}

Amini, Ibahim. 2009. Dunia Lain: Rukun Iman Kelima. Jakarta: AlHuda.

Amini, Ibrahim. 1997. Self Building. Qum: Bahman Press.

Bahri, Media, Zainul. 2011. Satu Tuhan Banyak Agama. Jakarta: Mizan.

Bidhendi, Mohammed. 1999. Causation According to Hume and Allāmah Tabātabā' '̄. Tehran: SIPRIn Publication.

Foucault, Michael. 2017. Power/Knowledge. Yogyakarta: Narasi.

Freud, Sigmund. 2002.Civilization and Its Discontents. Yogyakarta: Jendela Press.

Freud, Sigmund. 2015. Totem and Taboo. London: Routledge.

Gharawiyan, Mohsen. 2012. Filsafat Islam: Memahami Buku Daras. Jakarta: Sadra Press.

Gimball, Charles. 2003. Kala Agama Jadi Bencana. Bandung: Mizan.

Humaidi. 2015. Paradigma Sains Integratif Al-Farabi. Jakarta: Sadra Press.

Jung, Carl, Gustav. 2003. Memories, Dream, Reflections. Yogjakarta: Jendela Press.

Kalin, Ibrahim. 2010. Knowledge in Later Islamic Philosophy: Mulla Sadra on Existence, Intellect, and Intuition. New York: Oxford University.

Kant, Immanuel. 1998. Critique of Pure Reason. Newyork: Cambridge University Press.

Kung, Hans. 2017. Ateisme Sigmund Freud: Ketegangan Radikal Psikologi dan Spiritual. Yogjakarta: Labirin.

Kartanegara, Mulyadi. 2006. Gerbang Kearifan. Jakarta: Lentera Hati.

Komisi Nasional Hak Asasi Manusia. 2016. Laporan Tahunan: Kebebasan beragama dan berkeyakinan tahun 2016. Jakarta: KOMNAS HAM.

Mansulrudin, Muhammad Iqbal. Kebahagiaan Spiritual Berbasis Filsafat Ibn Sina. Jakarta: STFI Sadra, 201.

Mashkoor, Fakhri. 2011. Menjelajah Semesta Iman. Jakarta: AlHuda.

Munawwir, Ahmad, Warson. 1997. Kamus Arab-Indonesia AlMunawir. Surabaya: Pustaka Progressif.

Mutahahhari, Murtadha. 2011. Bedah Tuntas Fitrah: Mengenal Jati Diri, Hakikat, dan Potensi kita. Jakarta: Citra.

Mutahahhari, Murtadha. 2014. Filsafat Materialisme: Kritik Filsafat Islam tentang Tuhan, Sejarah, dan Konsep tentang Sosial Politik. Yogjakarta: Rausyan Fikr.

Mutahahhari Murtadha. 2002. Pengantar Pemikiran Shadra: Filsafat Hikmah. Mizan: Bandung.
Najati, Muhammad Utsman. 2002. Jiwa dalam Pandangan Para Filosof Muslim. Bandung: Pustaka Hidayah.

Nasr, Seyyed, Hossein. 2017. Al-Hikmah Al-Muta'aliyah Mulla Sadra: Sebuah Terobosan Baru dalam Filsafat Islam. Jakarta: Sadra Press.

Nasr, Seyyed, Hossein. 2003. Ensklopedi Tematis Filsafat Islam. Bandung: Mizan.

Pals, Daniel L. 2012. Seven Theories of Religion. Yogjakarta: IRCiSoD.

Piliang, Yasraf, Amir. 2011. Bayang-Bayang Tuhan: Agama dan Imajinasi. Jakarta: Mizan.

Rahman, Fadhlu. 1952. Avicenna's Psychology. London: Oxford University Press.

Robinson, Howard. 2003. Perception. Newyork: Routledge.

Rakhmat, Iones. 2014. Sciences and Values. Jakarta: Kanz Philosophia.

Roibin. 2010. Agama dan Mitor: Dari Imajinasi Kreatif Menuju Realitas yang Dinamis. Malang: Universitas Islam Negeri Maulana Malik Ibrahim.

Russell, Bertrand. 2016. Sejarah Filsafat Barat. Yogyakarta, Pustaka Pelajar.

Thabathabai, Muhammad, Husain. 1997. Bidāyatul Hikmah. Qom Syabkatul al-Fakri.

Sartre, Jean, Paul. 2015. Seks dan Revolusi. Yogyakarta: Narasi.

Sina, Ibn. 1998. al-Mabdā wa al-Maād. Tehran: Tehran Universitas Press.

Sina, Ibn. 1984. Remarks And Admonitions Part One: Logic. Toronto: Pontifical institute of Mediaeval Studies.

Smith, Huston. 2015. Agama-Agama Manusia. Jakarta: Serambi.

Suryabarta, Sumadi. 2011. Psikologi Kepribadian. Jakarta: Rajawali Pers.

Wahid, Abdul. 2014. Konsep Ilmu Pengetahuan Menurut Al-Ghazali dan Ibnu Rusdy serta Implikasinya terhadap Pengembangan Pendidikan Islam. Malang: Universitas Islam Negeri Maulana Malik Ibrahim.

Walid, Kholid, Al. 2012. Perjalanan Jiwa Menuju Akhirat: Filsafat Eskatologi Mulla Sadra. Jakarta: Sadra Press.

Wibowo, Setyo. 2011. Filsafat Eksistensialisme Jean Paul Sartre. Yogjakarta: Kanisius.

Yazdi, Taqi, Mizbah. 2010. Buku Daras Filsafat Islam. Jakarta: Sadra Press.

Yusufian, Hasan. 2014. Kalam Jadid: Pendekatan Baru dalam IsuIsu Agama. Jakarta: Sadra Press.

Ziai, Hossein. 2012. Suhrawardi dan Filsafat Iluminasi: Sang Pencerah Pengetahuan dar i Timur. Jakarta: Sadra Press 